\title{
THE REFORESTATION OF SAND PLAINS IN VERMONT
}

A-DISSERTATION

SUBMITTED TO THE FACULTY OF THE OGDEN GRADUATE SCHOOL OF SCIENCE IN CANDIDACY FOR THE DEGREE OF DOCTOR OF PHILOSOPHY

(DEPARTMENT OF BUTANY) 



\section{Tbe aniversity of Cbicago}

FOUNDED BY JCHN D. ROCKEFELLER

\section{THE REFORESTATION OF SAND PLAINS IN VERMONT}

A DISSERTATION

SEBNITTED TO THE FACULTY OF THE OGDEN GRADUATE SCHOOL OF SCIENCE IN CANDIDACY FOR THE DEGREE OF DOCTOR OF PHILOSOPHY

(DEPARTMENT UF BOTAXY)

$\mathrm{BY}$

CLIFTON DURANT HOWE

CHICAGO

I 910 
THE REFORESTATION OF SAND PLAINS IN VERMONT

A STLDY IN SUCCESSION

CONTRIBUTIONS FRONI THE HULL BOTANICAL LABORATORY I 35

CLIFTON DURANT HOWE

(WITH MAP AND FIFTEEN FIGURES)

\section{Geology}

The region of this study is known as the Burlington-ColchesterEssex sand plains, which are situated at the mouth of the Winooski River, that flows into Lake Champlain from the Vermont side. The history of the plains is intimately comnected with that of Lake Champlain. P'revious to the Glacial period the present valley of the lake was occupied by a river ${ }^{1}$ flowing northward. With the melting of the ice sheet a large lake was formed in the former river valley. After the Glacial period the sea invarled the region from the north. constituting what the older geologists called the Champlain epoch. At this time extensive berls of clay were laid down. The marine nature of these clays is demonstrated by the frequent occurrence of salt-water shells and by a skeleton of a whale found imbedded in them in the township of ('harlotte. The Champlain epoch closed with an elevation of land which raised the marine deposits to their present location, the highest elevation being about $100^{\mathrm{m}}$ above the present lake. With the withctrawal of the sea the valley was again occupied by a borly of fresh water, the present Lake Champlain.

At some time during the glacial and post-glacial history of Lake Champlain outlined above, bodies of water occupied three wellmarked levels. During each of these stages a delta was formed by the erosion deposits brought down by the Winooski Rixer. From the townships in which they are located, these deltas are designated on the accompanying map, from oldest to youngest, as the Essex delta, the Colchester delta, and the Burlington:fielta. The broken lines on the east side of each delta represent the beach lines of the lake (or sea) during the successive elevations. The doubling of the broken lines

I Balduin, S. P., Am. Geol. I 3:170-184.

Botanical Gazette, vol. 49] 




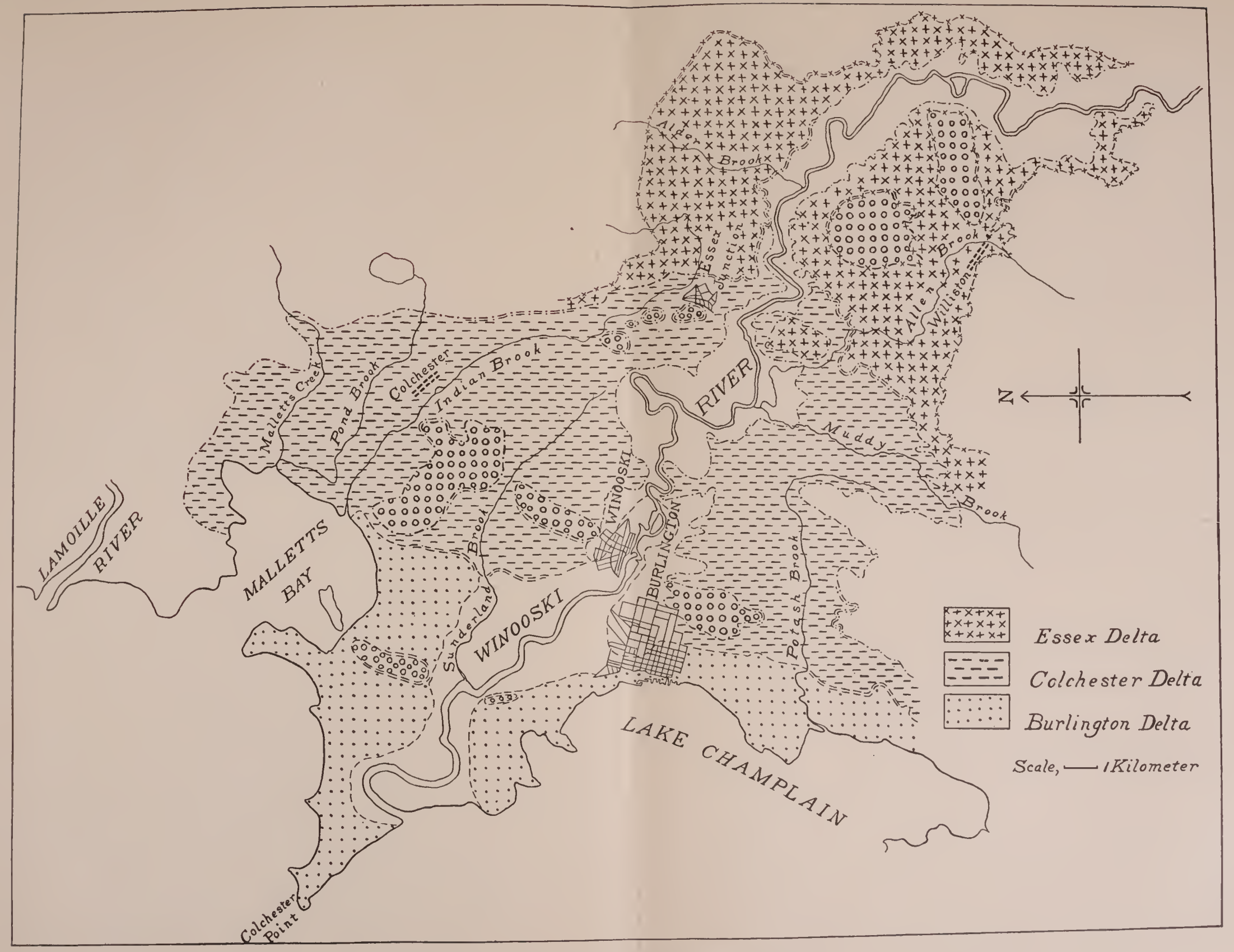

Map of the Burlington-Colchester-Essex Sand Pu.Ains 
tree. The prevalence of old white pine stumps beneath the present forests, as well as the numerous white pine stump fences throughout the sand plains townships, contribute corrolsorative evidence. The original forest evidently contained some large trees, judged from present standards. Thompson $(l . c$. ) states that he had observed trees $52^{\mathrm{m}}$ high, and adds that originally trees 43 to $55^{\mathrm{m}}$ high, having a diameter of $2^{\mathrm{m}}$, were not uncommon. Stumps in various stages of decay which were originally at least $1.5^{\mathrm{ml}}$ in diameter may be seen frequently on the sand plains.

In the clearings for settlement the commercial use of white pine was strictly local and rery limited. Later came the period of utilization on a larger scale. As early as $1800^{3}$ great rafts of pine logs taken from the sand plains were floated down to Quebec and thence exporter. In $\mathrm{I}_{42}$ the historian Thompsox (l. c.) asserterl that the forests of white pine in the Champlain region had practically disappeared. In 1850 (I)Avis, l. c.) the importation of white pine from Canada began.

The pitch pine (Pinus rigida) doubtless occupied small scattered areas on the most sterile soils. Black oak and white oak (Quercus velutina and $Q$. alba) are now common on the sand plains, and they probably formed a minor part of both the original white pine and pitch pine forests. Norway pine (Pinus resinosu) is now very local in its distribution on the sand plains, and it probably always was so. No record is to be found in regard to white birch (Betula populifoliu); for reasons to be discussed later it is doubtless much more abundant now than originally.

\section{Succession}

The succession on the Burlington, Colchester, and Essex sand plains is of two classes in respect to its place of origin, namely, upon cut-over areas and upon abandoned cultivated fields.

SLCCESSION ON CUT-OYER AREAS

As stated above, historical eridence clearly indicates that white pine was orginally the controlling tree on the Burlington, Colchester, and Essex delta plains. Only isolated trees of the original stand now

3 Davis, W. T., The New England states 3:1524-1526. 
remain. The conditions following the first cutting farored the invasion of the pitch pine upon areas which it had not previously occupied. In the first place, having no value at that time, it was not cut, so that seed trees were plentiful, a thing that cannot be said of the white pine; in the second place, pitch pine produces seed more abundantly than the white pine; and finally, being more light-demanding and being able to endure more sterile soil conditions, it is better adapted for regeneration on areas cleared by lumbering. Whatever the causes may have been, pitch pine became the controlling tree of the second generation, especially on the Colchester plain. A representative list chart in a stand 60 years old shows 2.5 pitch pine on $25^{\mathrm{sam}}$. Beneath on one square meter are is Myrica asplenifolia, 5 Pteris aquilina, 7 Kalmia angustifolia, 30 Traccinium pennsylzanicum. I I I'acrinium i'acillans, + Carex pennsylz'anica, 4 Diervilla Lonicera, 3 Solidago sp. (rosettes), 2 Rubus alleghenicusis.

The soil on the Burlington and Essex plains being as a whole less sandy, there is a larger proportion of mixed stands. On the average, black oak and white oak form one-third of the pitch pine stands. White pine of the second generation is more common on these two plains.

Three brickyards and a limekiln within the sand plains furnish a market for pitch pine as fuel, and the pitch pine forests have been cut for this purpose, so that by far the greater part of the area is now in its second cycle of reforestation. The stands are usually cut clean of both trees and saplings, the latter being taken down to $5^{\mathrm{cm}}$ in diameter. Sometimes a few isolated pines are left for seed trees, but they almost invariably die of the exposure resulting from clean cutting. The removal of the trees stimulated the development of the undergrowth, so that in most cases Myrica and Pteris became the dominant plants, and beneath them is a carpet of bhueberries ( $T$. pennsylanicum and I'. vacillans). If fire runs through, as it usually does periodically, the association becomes so dense as to allow no reproduction of trees. Often as many as 60 Myrica plants may be found on a square meter. The fire also keeps down the copprice shoots from the oak stumps. Some areas cleared 25 years ago are still practically without tree reproduction.

When the Myrica-Pteris association is 5 to 20 years old, and when 
it has not been rejuvenated in the meantime by fire, it begins to die out, apparently from natural causes. The open places thus made give an opportunity for the reestablishment of pitch pine. The few lots on which this was noted show pitch pine seedlings at the rate of

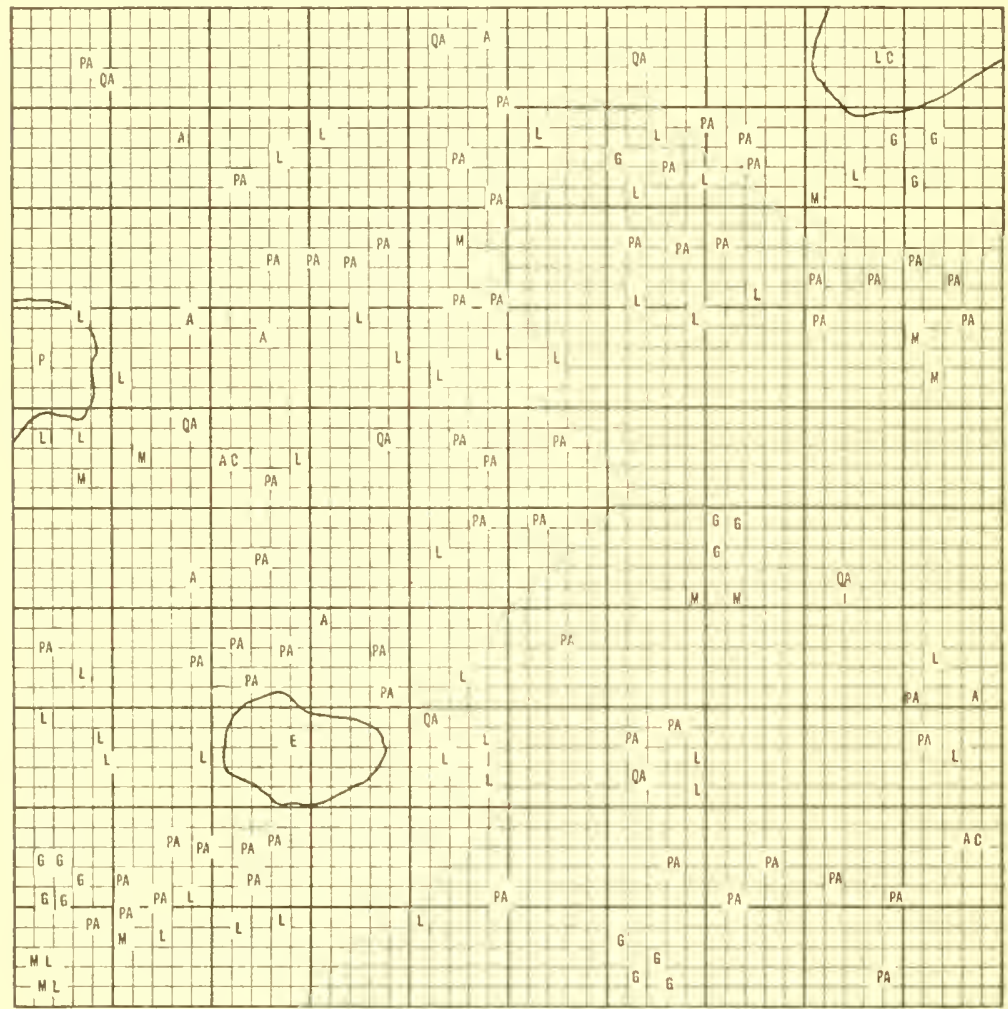

Fig, 1.-Sample plot I $_{5}$. Cleared is years ago, Culct ester plain, 5 meters square; under layer controlled by laccinium pennsylzanicum and Kalmia angustifolia; (2A. (. albas; A, Acer rubrum 5: AC, Amelanchier canadensis 2; PA, Pteris aquilina 50; 1, Lysimachia quadrifolia 3 s:; $\mathbf{G}$, Gaultheria procumbens $1 \mathrm{H} ; \mathrm{M}$, Myrica asplenifolia 0 ; LC, Lycopodium complanatum; P, Polytrichum; E. Epigaea repens; ML, Melampyrum lineare 2 .

one to $50^{\mathrm{sq}} \mathrm{m}$; older stages were not found. It seems probable, however, that eventually, if unmolested by man, such areas will regain their dominance of pitch pine.

In cases where fire is kept out from the time of clearing, however, 
reforestation takes place more rapidly. This is brought about first by the coppice shoots of the oak and by the filling-in of the interrening spaces by white birch (Betula populifolia), trembling aspen, red maple, and Amelanchier. 'Thus, on a lot cut two years ago, black

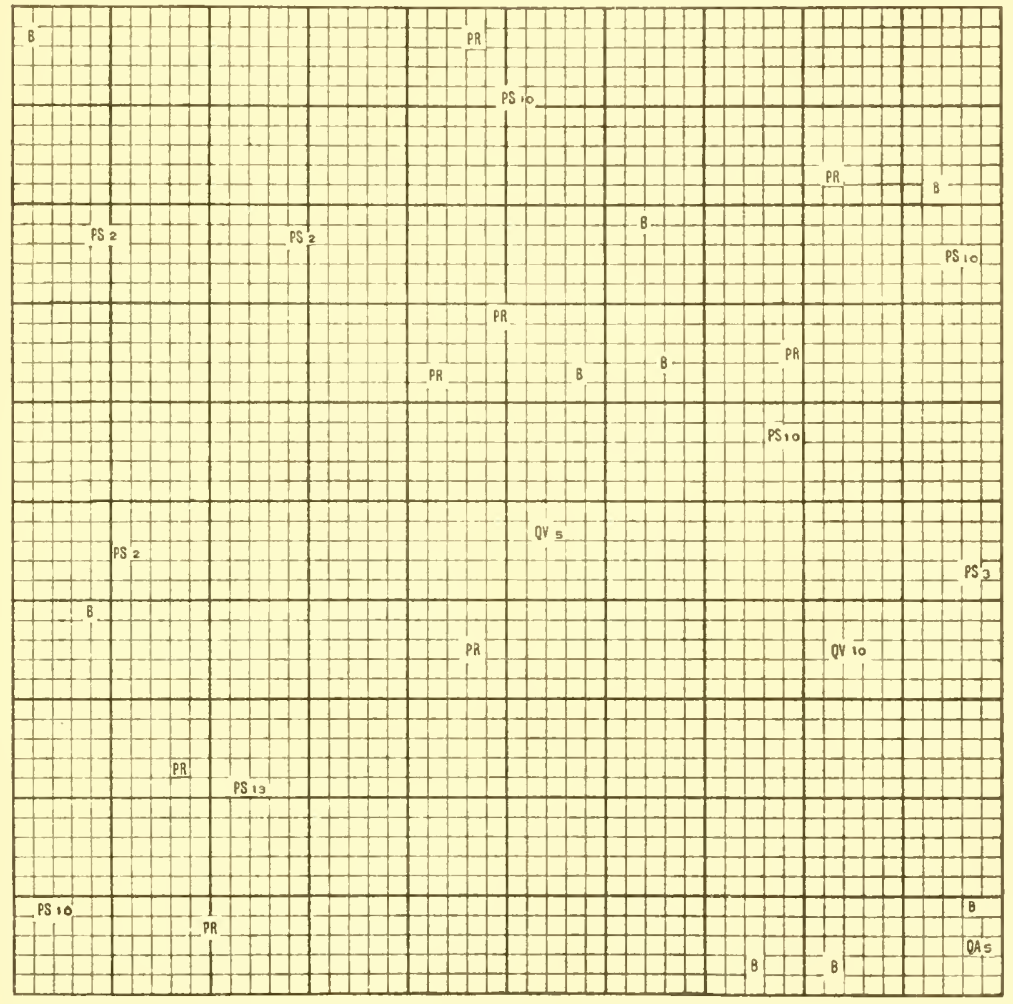

F1G. 2.- Sample plot 2. Pitch pine stand, 30 years old, Colchester plain, 5 meters square; under layer controlled by Pteris, Gaultheria, and Vaccinium acillans; PR, Pinus rigida 8; (2), Q. relulina 2; (2A, Q. alba 1; B, Belula populifolia ; (dving); PS, Pinus Sirobus.

oak coppice groups areraged three on $25^{\mathrm{sq}} \mathrm{m}$, while on the lot as a whole, ro per cent. of the coppice was white oak and 6 per cent. red maple. A dominant stand of pitch pine 24 years old was removed from the lot and a list chart showed on one square meter 9 Myrica, I 2 Pteris, 4 Populus tremuloides, 22 Kalmia angustifolia, 34 Vaccinium pennsylianicum, I Rubus allegheniensis. 
A stand of pitch pine 45 years old with suppressed black oaks averaging one and three respectively per $25^{\mathrm{sq}} \mathrm{m}$, was cut clean eight years ago. An average square meter now supports 3 coppice groups of black oak, 3 Corylus americant, I Amelanchier canadensis, I Salix humilis; under layer, Myrica and Pteris; beneath this, Kalmia, I'accininm iacillans, Lysimachia quadrifolia. The sample plot (fig. I) discloses the present conditions of a lot from which pitch pine was removed 15 years ago.

When the coppice stands of oak are about i 5 years old, they cover the area sufficiently to shade out much of the under vegetation. Myrica is the first to show the effects of this shading and Pteris goes next, while the species of Vaccinium persist longer than either Myrica or Pteris, $I^{r}$. idallans enduring the competition with the trees longer than I. penusylidnicum. At this stage the pines begin to reestablish themselves. P'jtch pine becallse of its greater intolerance comes into such areas very sparsely and rery slowly. Only one place was found where it had gained control, and even there the stand seems destined to be displaced by the more shade-enduring white pine, as the sample plot (fig. 2) shows.

For the reasons stated above, white pine is establishing itself on the clean-cut areas, formerly controlled by pitch pine, to a greater extent than the pitch pine. For example, in a lot cut t 2 years ago, on $25^{\mathrm{sqm}}$ one finds 8 white hirch saplings, 3 black oak coppice groups, 6 pitch pine seedlings, and 3 white pine seedlings; this is $100^{\mathrm{m}}$ from white pine seed trees. A distance of $50^{\mathrm{m}}$ from seed trees there are on $25 \mathrm{~mm} 3$ black oak coppice groups, 2 Amelanchier canadensis, I white birch, I red maple, 2 pitch pine seedlings, and Iz white pine seedlings. A still older stand is shown in sample plot no. 14 ( fig. 3).

The best white pine reproduction on clean-cut areas, however, is found where white birch controls. Thus in a clean cutting of 12 years ago, there are now 2 white birch coppice groups, 25 birch saplings and seedlings, o red maple coppice groups, 20 l'iburmm acerifolium, I Corylus amoricana, 3 Rhus typhina, 4 Myrica, 20 Vacinium vacillans, 2 white pine (S years old); Polytrichum commune and Carex pennsylanica dominant beneath. This plot is $100^{\mathrm{m}}$ from a white pine seed tree. Another plot of the same size $\left(25^{-59}\right)$ cleared 
I 5 years ago and only $5^{\mathrm{m}}$ from a seed tree, shows $4+$ white pinc seedlings mostly + and 8 years old. The seedlings are practically all on little hummocks covered with Polytrichum and Mitchella. The plot

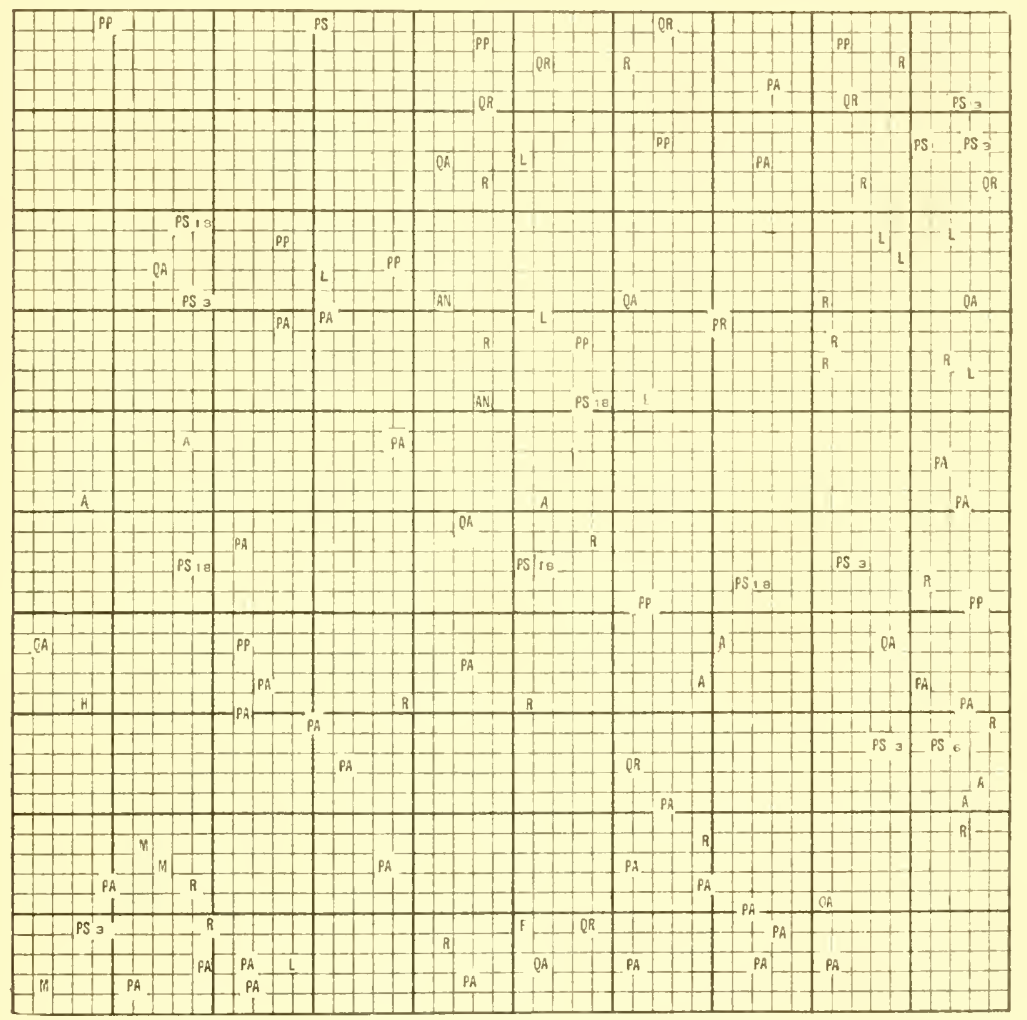

Fig. 3.--Sample plot i4. Cleared 20 years ago, Essex plain, 5 melers square; PS, Pinus Strobus 14; QA, Quercus alba S; (2R, (). rubra 7 ; A, Acer rubrum 6; PI', Prunus pennsylianica 10; PA, Pteris aquilina 20; R, Rubus allegheniensis $15 ; \mathrm{L}$, Lysimachia quadrifolia 9; $\mathrm{I}$, . Iyrica asplenifolia 3 ; $\mathrm{AN}$, Ara'ia nudicaulis 3 ; . V, Iraccinium a'acillans 2; F, Fragaria sp. I; H, Hamamelis 1 .

also contains one white pine sapling, 4 white birch and 3 black oak saplings, 3 Hammamelis, and 8 Corylus.

White birch in competition with oaks and pines persists only 20 to 30 years. Thus in a representative stand of this age one finds on $25^{\text {sq }} 5$ white pine ( 5 to I 4 years old), 2 black oak, I white oak, 3 white birch (nearly dead). When such stands are 35 years old the white 
birch usually has disappeared, and they arerage on $25^{\mathrm{sq}} \mathrm{m} 2.2$ white pine, 2.4 black oak, 0.6 white oak. Although the black oak appears in slightly greater numbers, the majority of them are suppressed and white pine dominates the stand.

Thus it will be seen that the clean-cut areas which pass through the white birch stage in their reforestation end in the control of the white pine, and that those areas passing through the oak coppice and Myrica-Pteris stages are more generally succeeding to white pine than to pitch pine.

\section{SLCCESSION UPON ABANDONED CLLTIVATED FIELDS}

The writer had no means of determining definitely how long the various fields had been cultivated before abandonment, but the indications are that the period was relative y short, on the average probably not more than io years. In some cases the fields never produced any other cultivated crop than rye, while in others they were cultivater 30 or 40 years before final abandonment. Occasionally an old field partially reforested is cleaned off and a second attempt at cultivation is marle.

Accorling to the conditions in which it takes place, the succession leading to the dominance of the forest upon abandonerl fields may be discussed under the following hearls:

I. Succession lacking the preliminary herbaccous stages. This occurs when a plowed field near a mature stand of trees happens to be abandoned in a heary seed year.

2. Succession lacking the sol-forming stage. The herbaceous stages are present but the complete control of grasses is absent or short-lived.

3. Succession possessing the sod-forming stage. The natural course of succession here is interrupted by man, for these areas are cropped for grass or pastured for a longer or shorter period before the trees begin to take possession.

I. SuCCESSION L.ICKING THE PRELIMINARY HeRb.iCEOL'S STAGES.This occurs when the abandonment of a plowed field and an abundant seed year are in conjunction. For example, a field on the Colchester plain first bore a crop of rye, then a crop of beans, and lay fallow the third year, when it was seeded down to white birch from the trees 
which surrounded the field. White birch seedlings two years old and Spiraea tomentosa now occupy the field at the rate of 53 and 4 respectively per square meter. I stand of pitch pine 6 years old showing 63 trees on $25^{\mathrm{sq}} \mathrm{m}$ came into existence in the same manner. A sample plot in this stand is given below $(f \mathrm{~g} . \mathrm{f})$. 'The oaks beneath are +

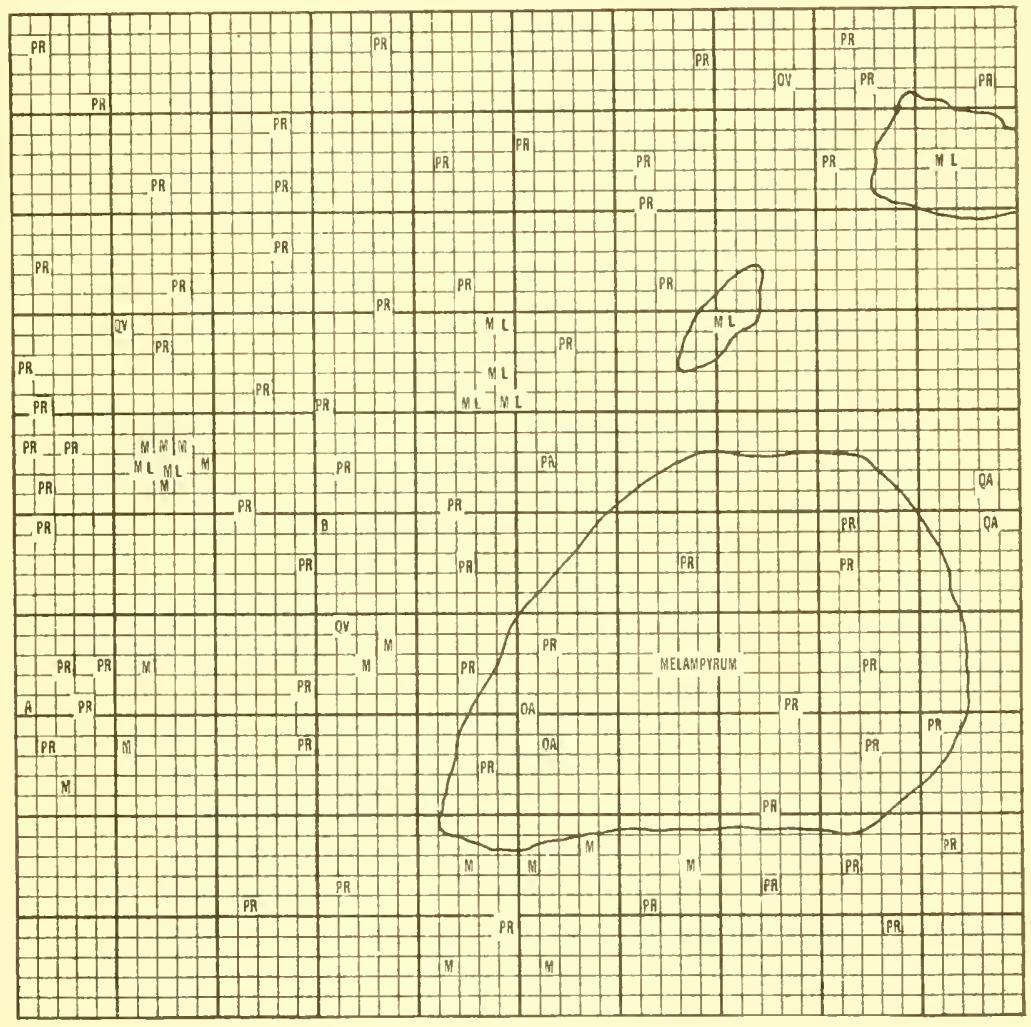

Fig. 4.-Sample plot I6. Pitch pine 16 vears old, on abandoned plowed field, Colchester plain, 5 square meters; PR, Pinus rigida $63 ;$ (2. A, Q. alba $5 ;$ QV, Q. relutina 3 ; ML, Melampyrum lineare; M, Myrica asplenifolia Io.

years old. Other dense even-aged stands of both white birch and pitch pine probably had a similar origin, although the history of their inception is not actually known.

2. SucCession LACKING THE SOD-FORMing STAGE.-The character of the regetation on a plowed field the first year after abandonment apparently depends upon the kind of weed seeds in the fertilizer. 
The quadrant below (fig. 5) gives the characteristic plants of a field which supported a crop of rye in the preceding year. Some fields may be controlled by Setaria glauca and Setaria ziridis; others by Ambrosia artemisiifolia and Erigeron canadensis. Fields under observation

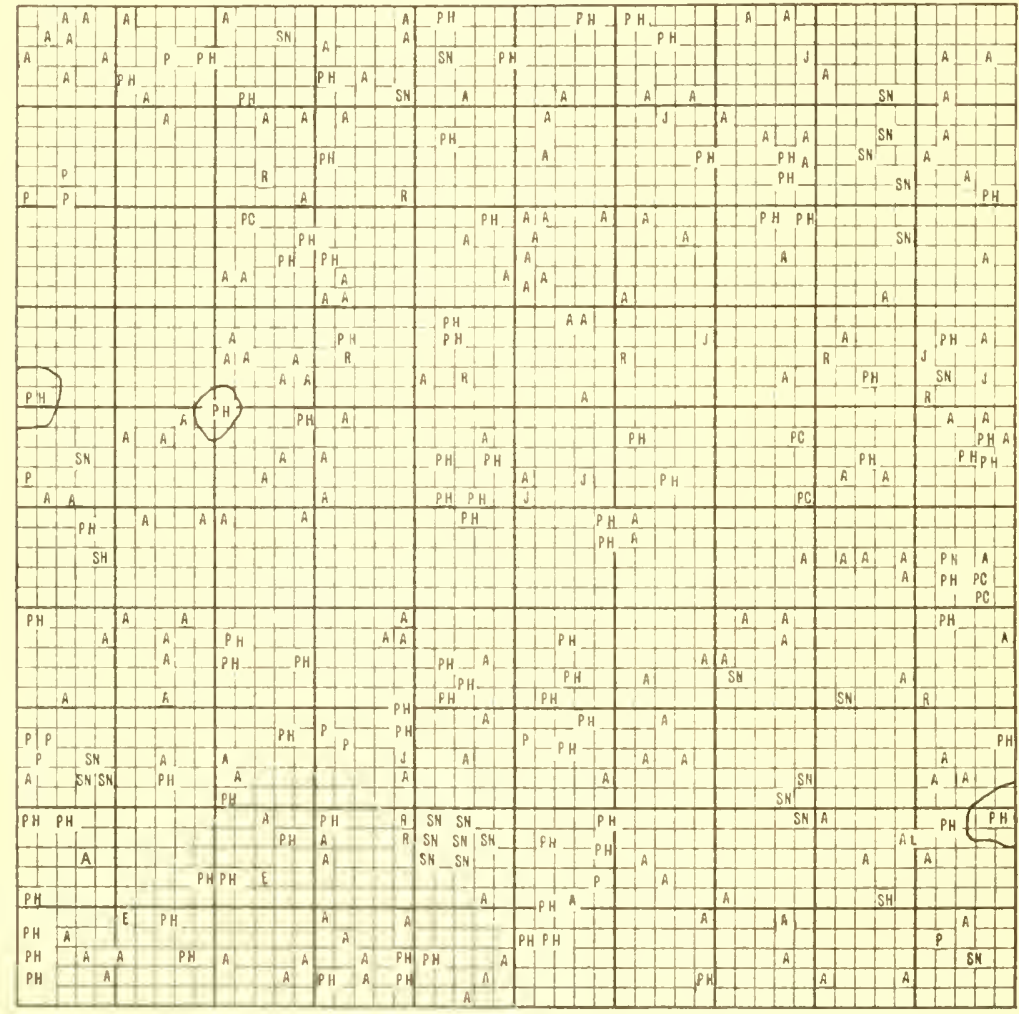

Fig. 5.- Sample plot 24. Plowed field, abandoned one year, Colchester plain. I square meter: A, Ambrosiu arlemisiafolia 155; PH, Phleum pralense $\mathrm{S}_{2} ; \mathrm{S}$, Solidago nemoralis 26; P, Poa compressu I 4; PC, Panicum capillare 4; R, Rumex Acetosella 7 ; I. Juncus sp. 6; E, Erigeron canadense 2; AL, Asler linariifolius 1.

for + years have remained uncler the dominance of these annuals. Later, Ocnothera biennis, Rumex Acetosella, Gnaphalium polycephalum. Antennaria plantaginifolia, Solidago memoralis, and Aster linariifolius control the old fields in patches. Between these patches occur scattered groups of Cyperus filiculmis, Carex pennsylranica, Andropogon scoparius, and Danthonia spicata. Groups of Poly- 
trichum appear in the most sterile places. Driving out the biennial and perennial weeds, the groups unite and form patches of moss a meter or more in diameter. The moss in turn may be crowded out by Cyperus and Danthonia, but it is never entirely displaced. Patches of Polytrichum often occupy one-third of the area in old fields.

Some of the plowed fields were abandoned because they began to blow away, and they have since become areas of shifting sand. 'This is notably the case in sereral places in the townships of Colchester and South Burlington. The finest sand is piled up in low rlunes and the coarser grades left behind are packed hard by the wind. Cyperus filiculmis and Panicum sanguinale are the pioneers on the compact sand; the former occurs in groups, while the latter advances en masse upon the sand. The open spaces between the groups of Cyerus are filled up by Polytrichum.

The patches of Polytrichum in the abandoned fields described above form ideal germinating beds for the seeds of pitch pine, white pine, and white birch. This is particularly the case when the P'olytrichum is young, before the dead leares and stems have accumulated sufficiently to prevent the seeds from reaching the mineral soil. Usually, however, Myrica precedes the tree invasion. It starts in the bed of Polytrichum and itself forms patches, killing out the moss immediately beneath it. The Polytrichum, however, persists around the margins of the Myrica group and in the moss, and under the protection of the Myrica one finds the tree seedlings.

The rapidity with which trees takc possession of the abandoned fields of this type chiefly depends upon the proximity of seed trees. Thus a field $370^{\mathrm{m}}$ from seed trees, abandoned 20 years ago, has only +1 white birch and 6 pitch pine saplings per hectare. When the pines get old enough to produce seed, a group of young trees will be formed about each mother tree. Fields showing two generations of pitch pine formed in this manner are of common occurrence and those showing three generations are not rare. The white birch, being shorter lived and less tolerant than the pine, is gradually suppressed, and the result is a pure stand of pitch pine of uneven age. A list chart in the field mentioned above shows on one square meter 16 Solidago memoralis, 24 Carex pennsylianica, is Lysimachia quadri- 
folia, 8 Aster linariifolius, 6 Danthonia spicata, 2 Ambrosia artemisiifolia, I I'iola arenaria, I group of Andropogon scoparius.

When the abandoned field happens to be near a mature stand of pitch pine, the reforestation is much more rapid. For example, an

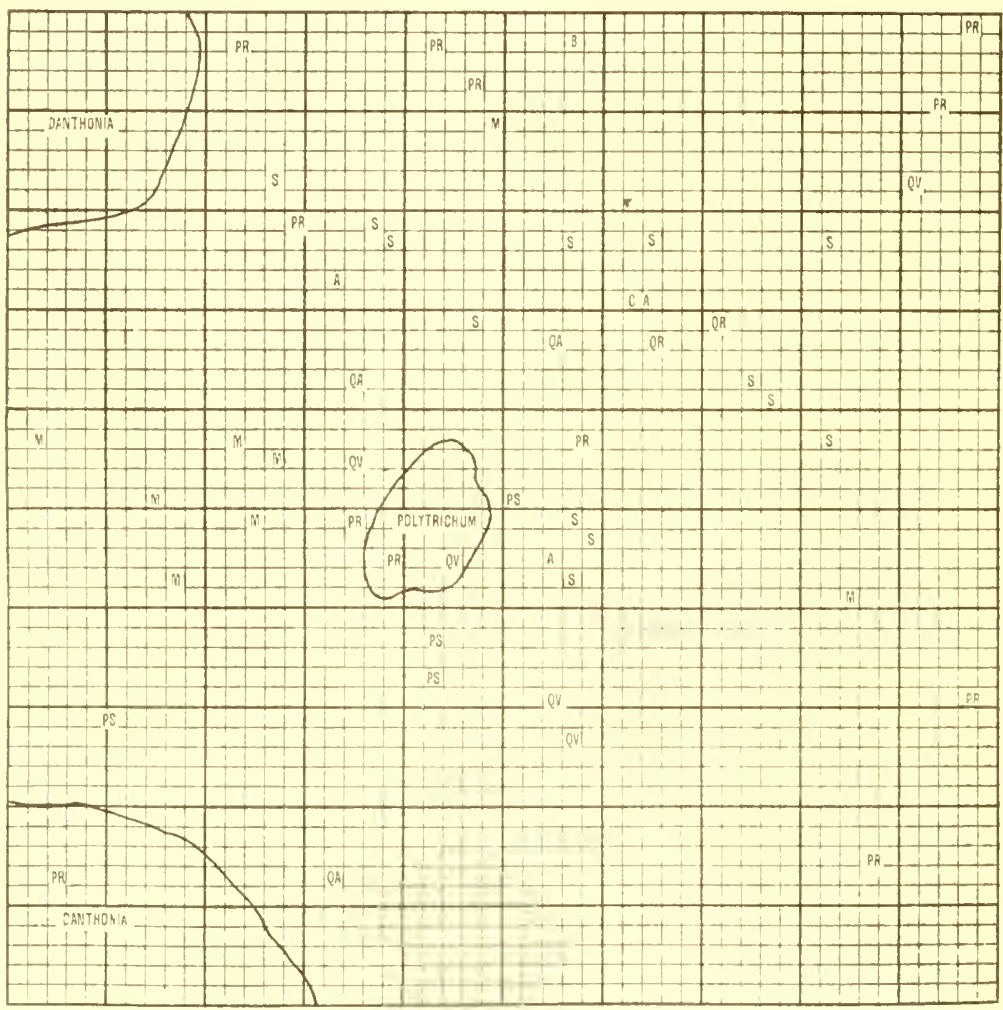

Fig. 0.- Sample plot Ir. Pitch pine 25 years old in an old field, Colchester plain,

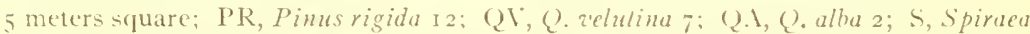
lomentosa 12; A, Acer rubrum 2; B, Betula populifolia 1: M, Myrica asplenifolia o; PS, Pinus Strobus.

old fickl on the Colchester plain has at $270^{\mathrm{m}}$ from the seed trees 1 pitch pine and 6.3 white birch saplings on $25^{\mathrm{s}} \mathrm{m}$; at $170^{\mathrm{m}}$ from the mother stand 3 pitch pine and $\mathrm{I} .3$ white birch; at $75^{\mathrm{m}}, 7$ pitch pine and no white birch on $25 \mathrm{sqm}$. In the second case the forest cover is complete and in the third case the stand is dense. At the greatest distance from the seed trees, the area between the birch and pine is 
controlled by Myrica and Pteris. As the trees become more abundant these are gradually crowded out, until beneath the dense stand they disappear. The saplings nearest the seed trees are 25 years old and those farthest from the seed trees are $\&$ years old.

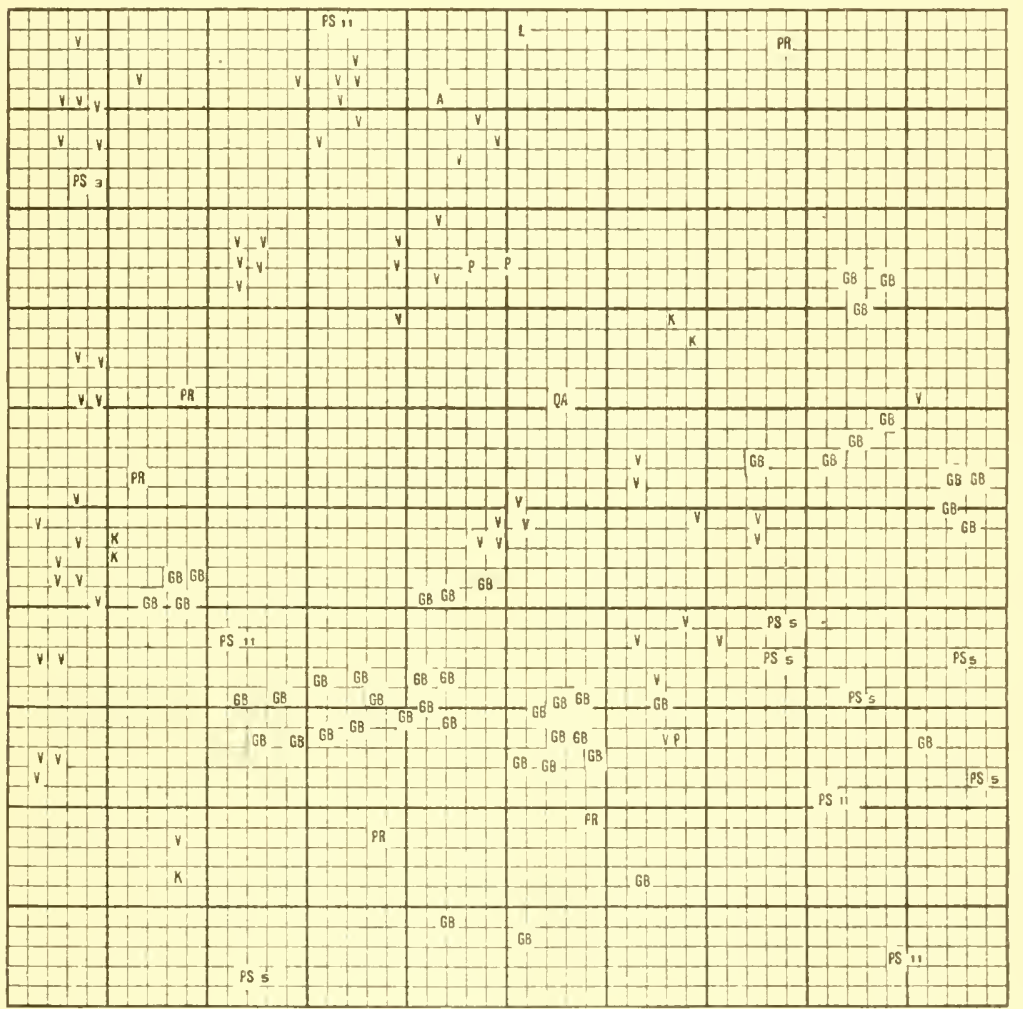

FIg. 7.-Sample plot io. Pitch pine stand 60 years old, Colchester plain, 5 meters square; under layer, Carex pennsylzanica; PR, Pinus rigida t; PS, Pinus Strobus II; V, I'accinium racillans 50; GB, Gaylussacia baccata 44; K, Kalmia angustifolia 5 ; (2A, Q. ulba I; L, Lysimachia quadrifolia I; IP, Taccinium pennsylianicum i 2; P, Pteris aquilina 26.

On p. I38 is given a sample plot (fig. 6) made in a stand of pitch pine 25 years old. Oaks are common in stands of this kind, but they are usually suppressed and apparently never become members of the dominant class.

An even-aged stand of pitch pine ( 36 years old on the stump) 
on the Essex plain averages 6 trees on $25^{-5 q \mathrm{~m}}$. Tacinium penusylzanicum forms a carpet beneath, and growing up through this, one finds on the average square meter I.3 Pteris, 5 Gaylussacia baccata, It Melampyrum lineare. S Carex pennsyitaniea. I Rubus allegheniensis, i A pocymum androsacmifolium.

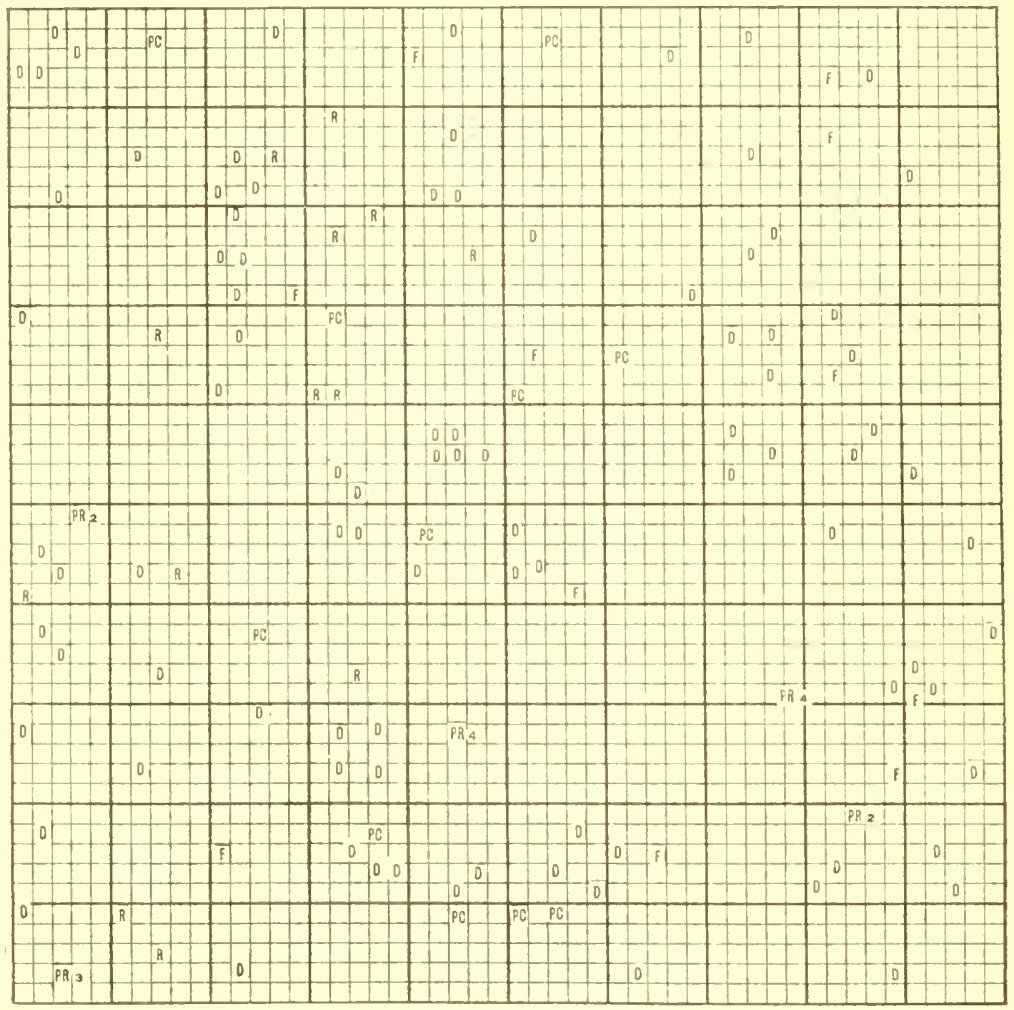

FIG. 8.- Sample plot 25. Danthonia-Polytrichum pasture being invarlerl by pitch pine; open patches occupied by Polytrichum; Colchester plain, I square meter; 1), Danhonia spicala so; R, Rumex Icelosella I 3; F, Fragaria rirginiana Io; PC, Panicum capillare 6: PR, Pinus rigida 2.

By the time pitch pine which has taken possession of the abandoned fields in the manner described above is 60 years old, the stand has become much less dense, averaging only one tree on $25^{\mathrm{sqm}}$. The ground beneath is much less shaded and the soil is richer from the accumulation of humus. At this point white pine quite commonly 
reproduces itself under the protection of the pitch pine, which is shown in the sample plot given on p. I to (fig. 7).

3. Succession possessing tile son-forming stage.-Many of the cultivated fields on the sand plains were "seeded down," bore crops of hay for a few years, and then were turned over to pasturage.

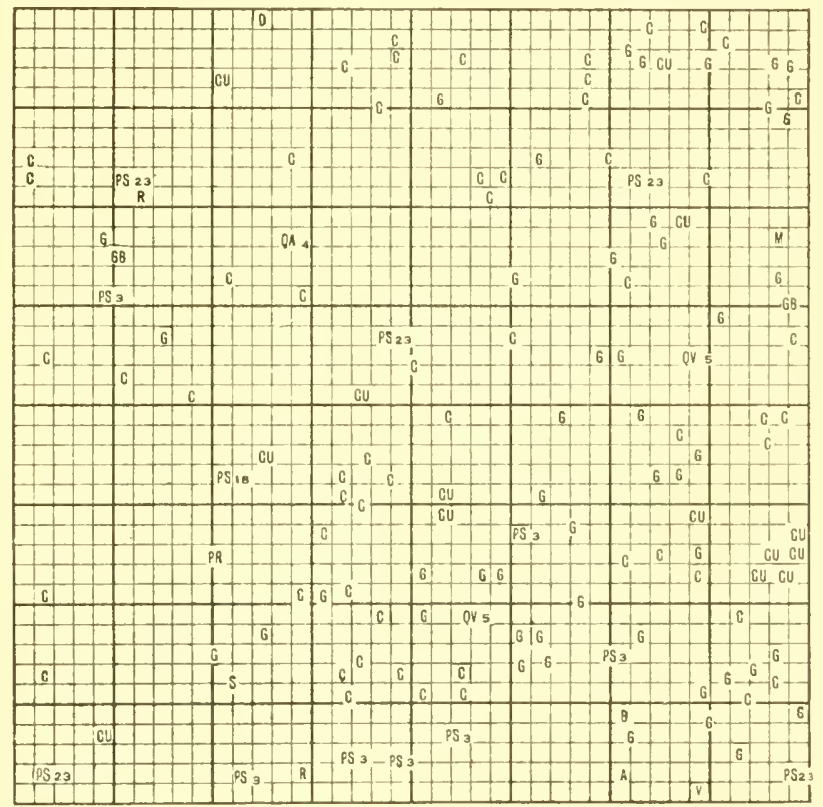

Fic. 9.- I'ermanent sample plot 35. Forty-year-clul stand of pitch pine, (int-

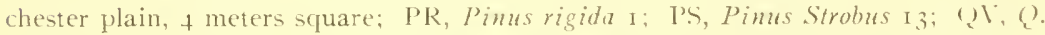
zelutina 2; Q.A, (). alba; C. (arex pennsylanica 56; (, Gaullheria procumbens fo; $\mathrm{CL}^{\top}$, Chimaphila umbellata I ; ( $\mathrm{B}$, (iaylussacia baccala 2; 1), Diervilla Lonicera $\mathrm{r}$; V, Faccinium z'acillans I; B, Betula populifolia 1; A, Aeer rubum I; R, Rubus allegheniensis 2; S, Solidago s1. I.

Other fields formed a sod naturally without artificial seeding and were used as pastures. The chief sorl-formers in this case were Poa pratensis and Danthonia spicata. After pastures formed in these two ways have been grazed for several years, they begin to lose their fertility. The first manifestation of this is the dying out of Poa pratensis, which is replaced by Danthonia. In course of time Danthonia gives way to Polytrichum commune. Most of the pastures 
on the area under consideration are in the Danthonia-Polytrichum stage. The principal associated species are Cyperus filiculmis. Panicum capillare, Spiraca tomentosa, Potentilla argentea, Solidago nemoralis. Rumer. Acctosella. Aster linariifolius.

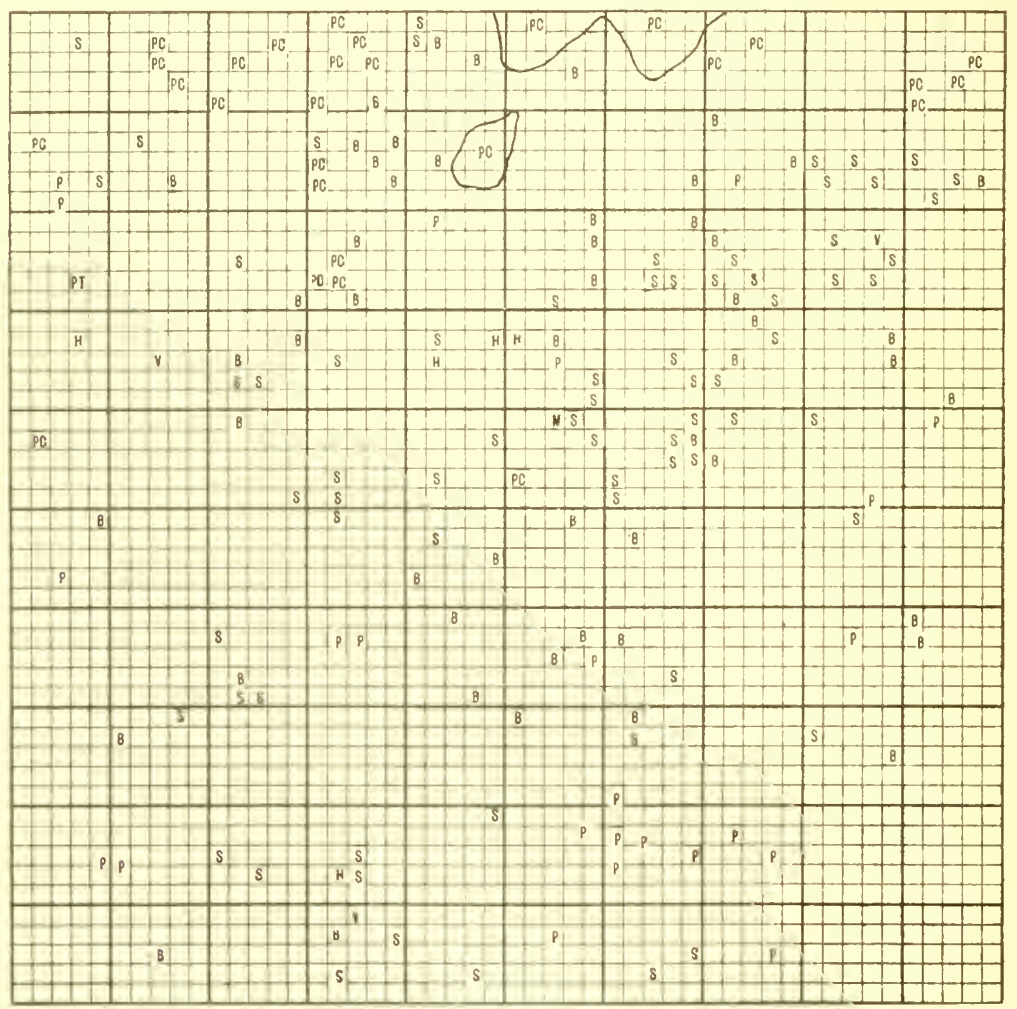

FIG. 10.-Sample plot 1. I)anthonia-Polytrichum pasture, showing one-year-old white birch, Colchester plain, I square meter; B, Belula populifolia 49 , at rate of 245 white birch on 25 square meters; 4 , Spiraca tomentosa 67; PC, Poa compressa 24; P, Panicum capillare 21; 11, Hypericum canadense 5; I, l'erbena haslata 3; PT, Populus tremuloides 1 .

As in abandoned plowed fields, beds of Polytrichum are centers from which the tree invasion begins. As in the former case also, pitch pine and white birch are most commonly taking possession of worn-out pastures. Adjacent to mature pitch pine, pastures are transformed into pure even-aged stands of that species, while those 
at a distance from the seed trees are eventually covered with uneren aged stands, as described for old fields in the preceding section. Sample plot no. 25 ( $\mathrm{fg}$. S) shows the character of a pasture in the first stages of possession by pitch pine.

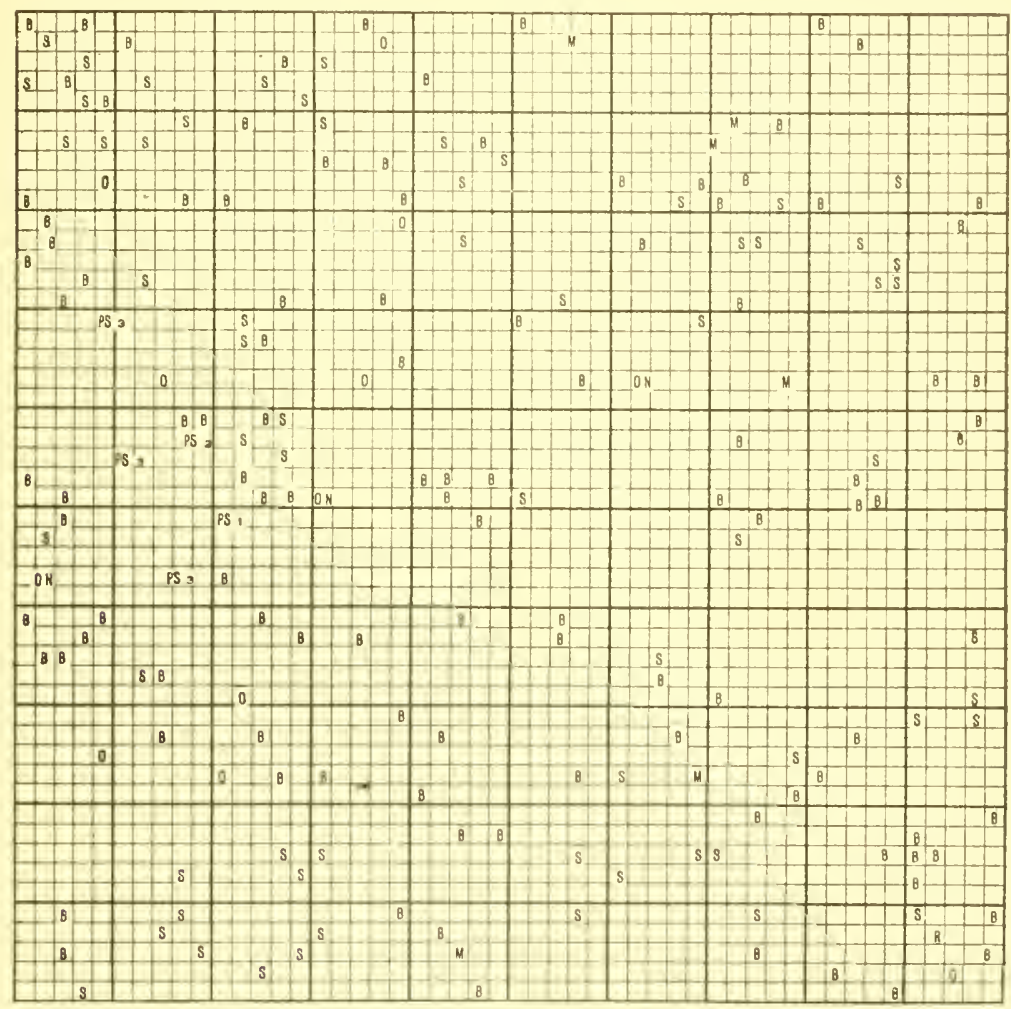

FIG. I I.- Sample plot 2. White birch 6 years old, pasture, Colchester plain, 5 meters square; a carpet of Polytrichum commune beneath; B, Betula populifoliu 105: S, Spiraea tomentosa 64; 1$),$ Osmunda cinnamomea 8; . I, . Myrica asplenifolia 4 ; ON, Onoclea sensibilis 2; MU, Monotropa uniflora 2; R, Rubus allegheniensis 1 ; PS, Pinus Strobus 5 .

Ten stands 5 to $I_{5}$ years old areraged $3+$ trees on $25^{\mathrm{sq}} \mathrm{m}$, while ten stands 25 to 30 years old averaged 7 trees. The older stands of pitch pine show regeneration of white pine beneath them, and plots like no. Io (fig. 7) may be commonly found in the old pastures as well as in the abandoned fields. In one case white pine seedlings and saplings 
at the rate of 70 per $25^{\text {sq } \mathrm{m}}$ were found beneath a 24 -year old stand. There were 7.5 pitch pine on $25^{\mathrm{sq} \mathrm{m}}$. Unfortunately these stands are periodically burned and the seedlings are killed, so there is little opportunity of observing the older stages of this undergrowth of white pine. On the Macomber lot, however, where fire has been rigorously

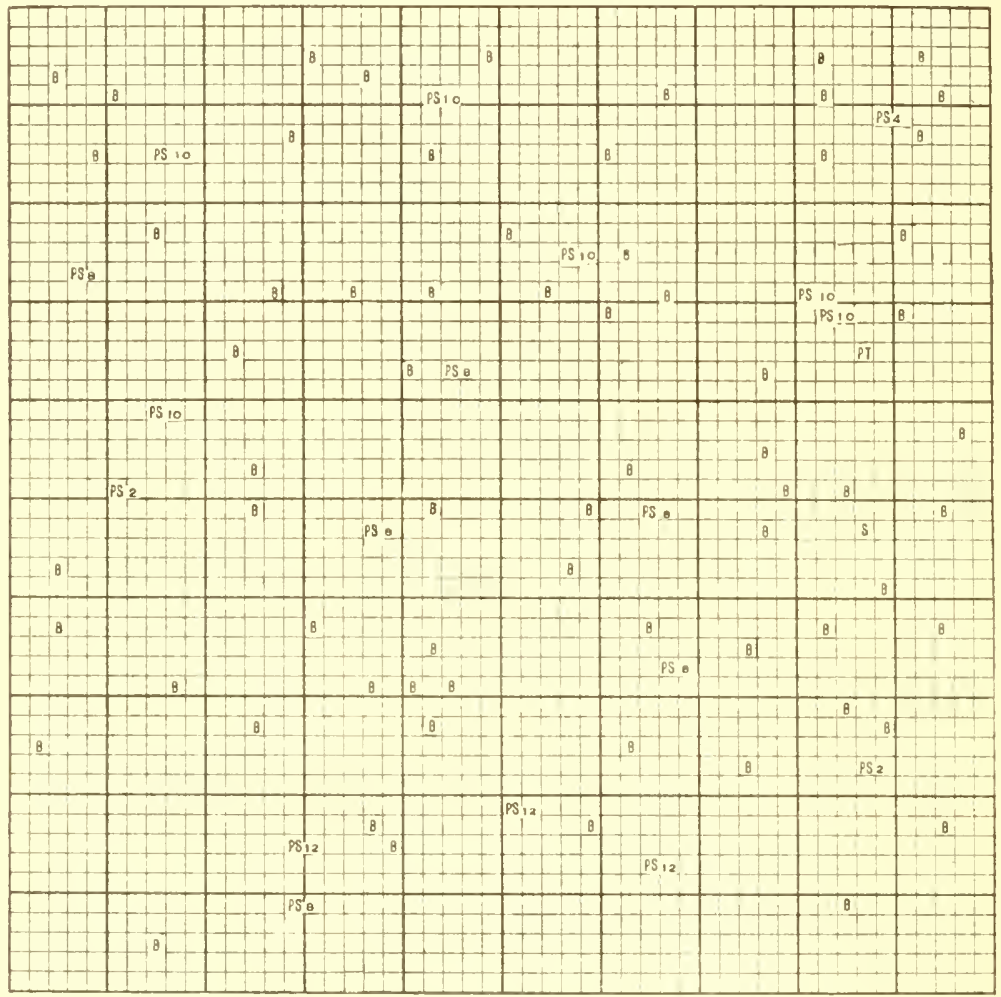

FIG. 12.- Sample plot 9. White birch 15 years olı, Colchester plain, 5 meter: square: under layer, Polytrichum, ()noclea sensibilis, Ruhus hispidus; 13, Betula populifolia os: PS, Pinus Strobus is: P'T, Populus tremuloides 1 ; S. Sipiraea tomentosa $\mathrm{I}$.

excluded for many years, one may find the older stages. Sample plot $35(f i g . y)$ shows white pine 23 years old beneath pitch pine 40 years old. There is little doubt of the ultimate control of such pitch pine stands by white pine, were forest fires excluded.

White birch in the old pastures usually forms dense pure stands. The series of stands shown in figs. $I O-13$ illustrates displacement of 
white birch by white pine. It will be noted that the numbers of white birch on the unit area for the ages given are 2.45,105, 68, and I6; and that the numbers of white pine increase as follows: $0,5,18,46$. This illustrates the most striking fact in the course of succession on worn-out pastures, that is, gradual replacement of white birch by

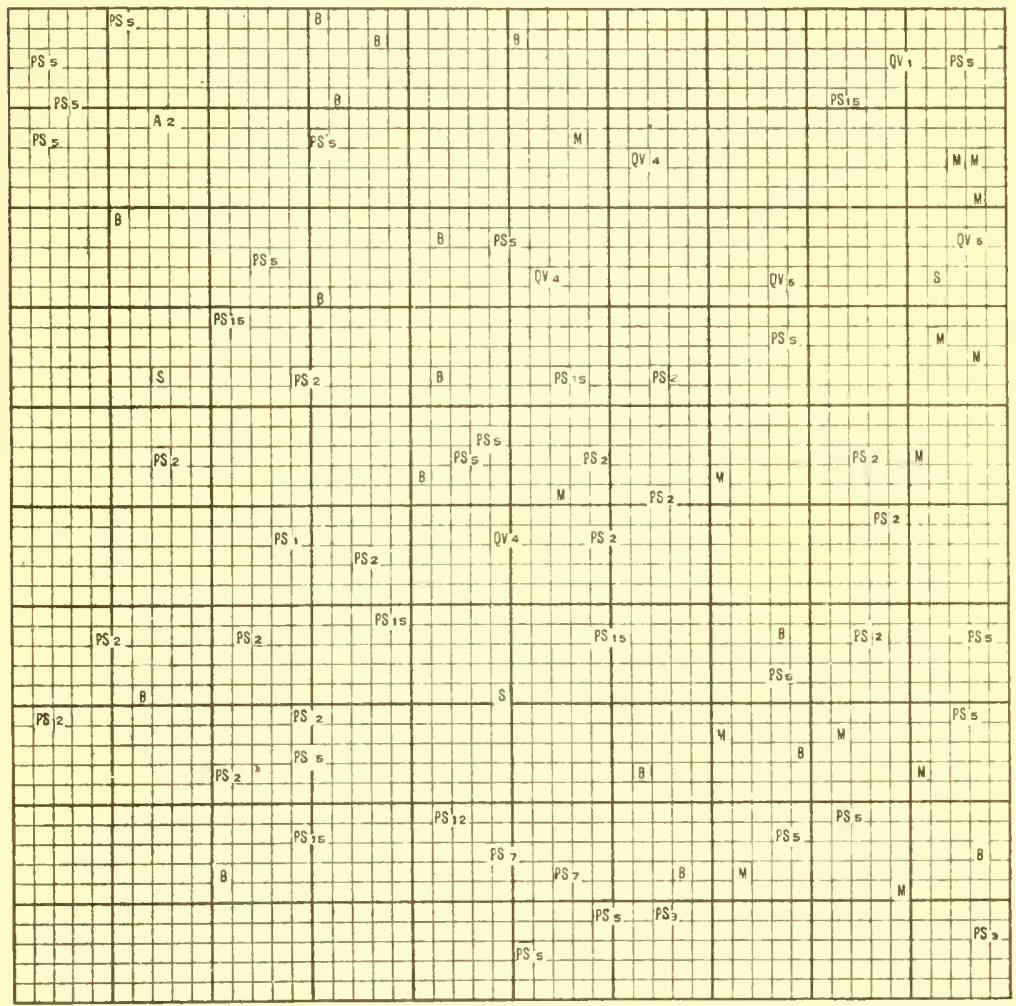

Fig. 13.-Sample plot 17 . White birch 25 years old, 5 meters square, $50^{\mathrm{m}}$ from white pine; under layer Polytrichum and Rubus hispidus; $\mathbf{B}$, Betula populifolia 16 ; PS, Pinus Strobus 16; QV; Cuercus velutina 6; M, II yrica asplenifolia 1 †; S, Spiraea tomentosa 3 ; A, Acer rubrum 1.

white pine. If a stand of white birch is within proper distance from white pine seed trees, the birch acts as a nurse tree to the pine.

In the clearing of the sand plains occasional white pine trees were left along the margins of wood lots and along highways. Such trees became the originators of numerous pure stands of white pine in the 
old pastures. Sample plot no. 37 ( fig. If) gives the character of the pasture when the white pine invasion begins.

Stands of all ages occur from the seetling stage to mature trees. As in the case of pitch pine, one may find patches of white pine con-

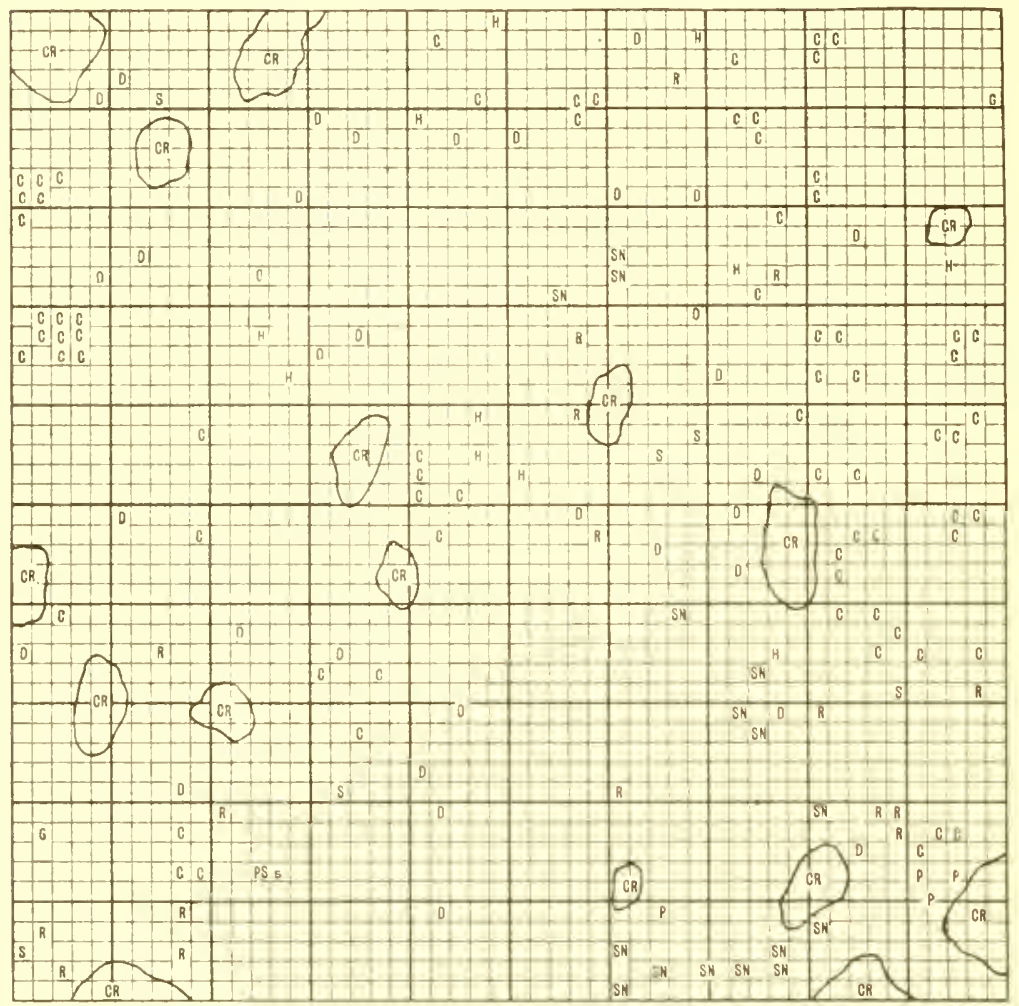

Fig. If. Sample plot 37. Pasture being invaded by the white pine, Colchester plain, I syuare meter; C, ( yperus filiculmis 72 ; $\mathrm{D}$, I) anthonia spicata $34 ; \mathrm{R}$, Rumex Acetosella I6; SN, Solidago nemoralis If; H, II ypericum canadense Io; S, Spiraca tomentosa 6; P, Panicum capillare 4; C R, Cladonia rangifera; G, Guaphalium polycephalum I.

taining three generations of trees, each generation even-aged and in pure stand. The stands now in the process of installation offer a good opportunity to study the abundance of seedlings in relation to the distance from the mother tree. For example, the number of seedlings were counted on plots $5^{\mathrm{m}}$ square with the following results: 30 to $25^{\mathrm{m}}$ 
from the seed tree, + seedlings; 25 to $20^{\mathrm{m}}, 17$ seedlings; $201015^{\mathrm{m}}$, 24 seedlings; I 5 to IO $^{\mathrm{m}}, 25$ secethings; io $105^{\mathrm{m}}, 35^{\text {secellings; }} 5^{-\mathrm{I}^{\mathrm{m}}}$ from a vertical line dropped from the outer margin of the crown of the seed tree, 85 seedlings. 'The seedlings were 3 and 8 years old.

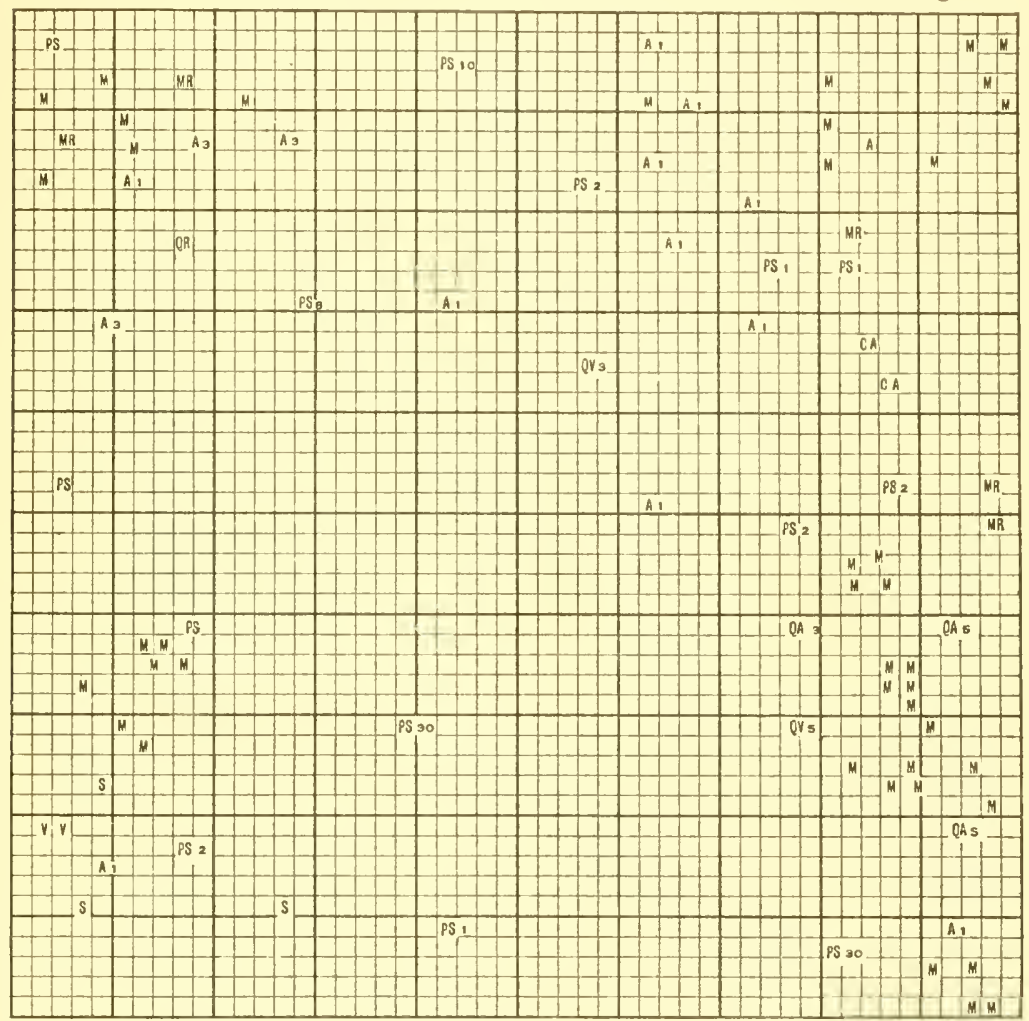

FIG. 15.- Sample plot 13. White pine stand 35 years old, an abandoned cultivated field, Essex plain, 5 meters square; J', Pinus Strobus I 4 ; QV', Q. velutina 2; (2.A, Q. alba I; QR, Q. rubra I; A, Acer rubrum It; C.A, Corylus americana 2; M, Maianthemm canadense 35; M R, Mitchella repens 5; V, I'accinium vacillans I; S, Solidago sp. (rosette) 3 .

During their sapling stage the pure stands of white pine are usually so dense as to exclude secondary regetation, but by the time they are 30 years old they have become thinned out sufficiently to allow undergrowth. This is illustrated in sample plot no. I3 (fig. 15), made beneath a stand 35 years old. Seedling and sapling oaks are of com- 
mon occurrence beneath the older white pine in sufficient numbers to indicate an eventually mixed stand should they persist.

In the discussion of succession on abandoned fields it has been shown that white pine is gradually regaining control of the areas on which it was once dominant, by the direct reseeding leading to the establishment of pure stands, indirectly by the supplanting of white birch stands, and, were human interference withdrawn, by the replacement of pitch pine stands.

I have employed the month of vacation for the past six years in the study of the sand plain vegetation. Forty-five permanent sample plots in the stands, representing various stages of succession, have been established and mapped, and those have been given above which in my judgment best represent the conditions discussed. Most of these plots will be kejt under observation in the future, so that definite records of the changes in situ may be recordert. Besides these, the character of the vegetation has been recorded by roo list charts.

While investigations have been conducted in the effort to determine what changes in ecological conditions have brought about the changes in regretation on the sand plains, I feel that they have not progressed far enough to justify their publication. Therefore it seemed best to make the present paper simply a record of succession. The nomenclature is that of GRAY's New mamal of botany.

\section{Summary}

Pitch pine succeeder to the control of areas from which the dominant white pine had been removed.

White pine, however, is gradually regaining its control on cut-over areas, as well as on abandoned fields, by its actual replacement of white birch stands and by its probable displacement of the pitch pine stands.

'The work upon this paper was begun at the suggestion of Dr. L. R. JoNes of the University of V'ermont and was continued under Dr. H. C. Cowles of the University of Chicago. I wish to express my appreciation of the kindly criticism and encouragement received from them.

UNIEERSITY OF TORONTO 

LIBRARY Or CUNGRESS

I I H H

(I) | I. I.

00009225730 